\title{
DIAPHRAGMS OF WATER PLANTS
}

\section{EFFECT OF CERTAIN FACTORS UPON DEVELOPMENT OF AIR CHAMBERS AND DIAPHRAGMS}

L A E T IT I A M. S OW

\section{(WITH THREE FIGURES)}

The experiments reported in this paper were started at Wellesley College in I9I4-I9I5, and were continued at the University of Chicago during the winter of I9I5-19I6. It was intended to repeat the experiments and confirm the results, but as it has been impossible to do so, it seems better to report the work in its present incomplete condition than to delay its publication any longer. Thanks are due the Association of Collegiate Alumnae for the grant of the Alice Freeman Palmer Memorial Fellowship for I9I5I9ı6, the Missouri Botanical Garden for the material of Scirpus validus which was collected and started at St. Louis, and the botanical staff of the University of Chicago for their cordial cooperation in placing the facilities of the laboratory at my disposal.

\section{Water}

As the general impression is that an increase in the water content of the soil produces an increase in the amount of air-containing tissue, culms of Scirpus validus were allowed to grow alternately under water and in the air, in order to note the effect of the change upon the air spaces and diaphragms.

\section{EXPERIMENT I}

In order to be sure that the part studied actually grew under the desired condition, it was necessary to ascertain the region of growth of the stem. Consequently in I9I4-I9I5 culms were marked in $2 \mathrm{~mm}$. sections from the tip downward. In some cases the marks extended to the sheathing scale leaves at the base (called "to sheath" in table I); in others the sheath was stripped off and the marks carried down the stem to the rhizome (called "culm" in the table). DD 5 showed a discrepancy between the

[Botanical Gazette, vol. 69 
millimeters of growth and the distance of the last mark from the ground. As it grew $33 \mathrm{~mm}$. and the last mark was $38 \mathrm{~mm}$. from the ground, the difference of $5 \mathrm{~mm}$. might mean that three marks had disappeared. If the first was at the base, the stretching, in destroying these marks, could not have extended farther than $5 \mathrm{~mm}$., as the last mark visible was clear cut and $2 \mathrm{~mm}$. from the one next above it. The discrepancy was more likely to have been the result of faulty measurements.

TABLE I

REGION OF GROWTH IN Scirpus validus

\begin{tabular}{|c|c|c|c|}
\hline Pot & Culm no. & Marking & Region of growth \\
\hline 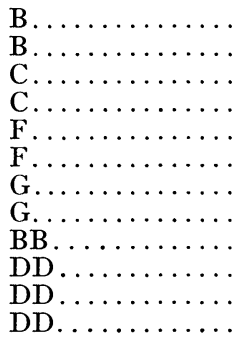 & $\begin{array}{l}\text { I } \\
2 \\
3 \\
4 \\
3 \\
4 \\
4 \\
5 \\
4 \\
2 \\
4 \\
5\end{array}$ & $\begin{array}{l}\text { To sheath } \\
\text { To sheath } \\
\text { To sheath (?) } \\
\text { To sheath } \\
\text { To sheath (?) } \\
\text { To sheath } \\
\text { Culm } \\
\text { Culm } \\
\text { To sheath } \\
\text { To sheath } \\
\text { Culm } \\
\text { Culm }\end{array}$ & $\begin{array}{l}\text { No growth } \\
\text { Below top of sheath } \\
\text { Below top of sheath } \\
\text { No growth } \\
\text { No growth } \\
\text { Below top of sheath } \\
\text { Below last mark } \\
\text { Below last mark } \\
\text { Below top of sheath } \\
\text { No growth } \\
\text { Below last mark } \\
\text { Below last mark (?) }\end{array}$ \\
\hline
\end{tabular}

EXPERIMENT 2

In February I9I5, I I culms were marked, 6 to the top of the sheath and 5 on the stem to the base. After a period of growth all marks were clear cut, and showed no separation. This may mean that all growth took place below the last mark, or that some of the marks had disappeared. To test this, experiment 3 was started.

\section{EXPERIMENT 3}

In March I9I5, 4 culms were marked to the base, as just described, and the number of marks counted. One culm did not grow. In the second culm, after one day, the lowest mark had disappeared; the second mark was $4 \mathrm{~mm}$. from the base and was perfectly clear cut. The other marks had not changed. In the third culm, after 7 days, the first mark was at the base on a piece of sheath; the second was clear and I3 mm. above the base. In the fourth culm, after 7 days, the first mark was on a piece 
of sheath; the second was clear and $4 \mathrm{~mm}$. from the base. The third culm was marked again, and by the next day the first mark had disappeared and the second mark was $4 \mathrm{~mm}$. from the base. From these experiments it seems reasonable to conclude that the growth of Scirpus validus takes place within an extremely short distance of the base, possibly as short as 2 or $3 \mathrm{~mm}$.

\section{EXPERIMENT 4}

While the foregoing experiments were in progress, others were started, to test the effect of the medium upon the growing region. Pieces of rhizome were potted, practically at the surface of the soil, and placed under water. When the culms were well grown, the water was allowed to evaporate until the surface of the soil was exposed to the air. When the water level had fallen to about an

TABLE II

VARIATION IN GROWTH OF Scirpus validus WHEN CHANGED FROM ONE MEDIUM TO ANOTHER

\begin{tabular}{|c|c|c|c|c|c|c|c|c|c|}
\hline \multirow{3}{*}{ Рот } & \multicolumn{4}{|c|}{ WATER TO AIR } & \multicolumn{5}{|c|}{ AIR TO WATER } \\
\hline & \multicolumn{2}{|c|}{ Accelerated } & \multicolumn{2}{|c|}{ Retarded } & \multicolumn{2}{|c|}{ Accelerated } & \multicolumn{2}{|c|}{ Retarded } & \multirow{2}{*}{$\frac{\text { Unchanged }}{\begin{array}{c}\text { No. of } \\
\text { culms }\end{array}}$} \\
\hline & $\begin{array}{l}\text { No. of } \\
\text { culms }\end{array}$ & $\underset{\text { day }}{\text { Mm. per }}$ & $\begin{array}{l}\text { No. of } \\
\text { culms }\end{array}$ & $\underset{\text { day }}{\text { Mm. per }}$ & $\begin{array}{l}\text { No. of } \\
\text { culms }\end{array}$ & $\underset{\text { day }}{\text { Mm. per }}$ & $\begin{array}{c}\text { No. of } \\
\text { culms }\end{array}$ & $\underset{\text { day }}{\text { Mm. per }}$ & \\
\hline & I & I6.0 & I & 22.0 & I & 0.5 & & $\cdots$ & I \\
\hline B.. & $\cdots$ & $\ldots \ldots \ldots$ & $\cdots$ & $\ldots \ldots$ & I & $4 \cdot 5$ & & . & $\ldots \ldots$ \\
\hline C.... & $\cdots$ & $\ldots \ldots$ & I & 5.0 & 2 & $\left\{\begin{array}{l}4 . \\
\text {. }\end{array}\right.$ & $\cdots \cdots$ & $\cdots$ & $\cdots \cdots \cdots$ \\
\hline D. & $\ldots$ & $\ldots$ & I & II.O & I & $\begin{array}{l}1.5 \\
1.0\end{array}$ & $\ldots$ & $\cdots$ & I \\
\hline & $\cdots \cdots$ & $\ldots \ldots$ & I & 12.0 & I & I. 5 & I & I & $\ldots \ldots$ \\
\hline G. . & $\ldots$ & $\ldots \ldots$ & .. & & I & 5.0 & $\ldots \ldots$ & $\cdots$ & $\ldots \ldots$ \\
\hline AA... & I & 2.0 & 2 & $\left\{\begin{array}{r}15.0 \\
2.5\end{array}\right.$ & 2 & $\left\{\begin{array}{l}2 \cdot 5 \\
3.0\end{array}\right.$ & & $\left|\begin{array}{l}\cdots \\
\cdots \\
\cdots\end{array}\right|$ & $\begin{array}{c}\mathrm{I} \\
\cdots\end{array}$ \\
\hline BB. & & & I & 24.0 & 2 & $\left\{\begin{array}{l}1.0 \\
2.0\end{array}\right.$ & $\begin{array}{c}\mathrm{I} \\
\ldots \ldots\end{array}$ & $\begin{array}{r}4 \\
\ldots\end{array}$ & \\
\hline CC... & I & 42.0 & & & 2 & $\left\{\begin{array}{l}3 \cdot 0 \\
2 \cdot 5\end{array}\right.$ & $\cdots \cdots$ & $\cdots$ & \\
\hline DD ... & & $\ldots \ldots \ldots$ & I & I $7 \cdot 5$ & I & 2.0 & $\cdots \cdots$ & $\ldots \ldots$ & $\cdots$ \\
\hline EE. & & & & & 2 & $\left\{\begin{array}{l}1.0 \\
6.5\end{array}\right.$ & & $\cdots$ & \\
\hline Aver & $\cdots$ & 20.0 & & I3. 6 & & 2.6 & & $2 \cdot 5$ & $\ldots \ldots$ \\
\hline Total nos. & 3 & & 8 & & I6 & & 2 & & 3 \\
\hline
\end{tabular}


inch below the surface of the soil, it was maintained at this height by regulating the amount of water in the surrounding vessel. This allowed the culms to grow in the air, while the roots had an abundant supply of water. All were grown under these conditions for a certain period, which differed for the different pots, after which they were again submerged. Careful measurements of the growth were made throughout the experiment, and at its close longitudinal sections were made in the regions which had grown under the different conditions, and measurements made of the distances between the diaphragms. The results are shown in the tables.

EfFect ON GROWTH.-From table II it might be concluded that a change from water to air retards growth, and the reverse change

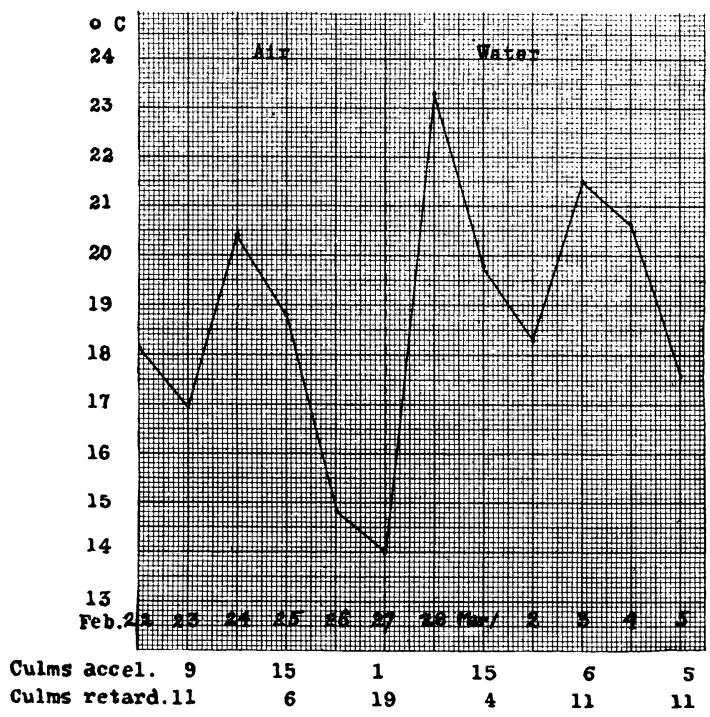

FIG. I.-Effect of temperature and surrounding medium upon growth of culms of Scirpus validus. accelerates it. Tw'o facts, however, must be noted: ( $\mathrm{I}$ ) in some cases in the same pot one culm was growing faster after the change, while another was growing more slowly; and (2) the temperature was not controlled. Toward the latter part of the experiment an effort was made to keep a record of the variation in temperature. A recording thermometer was not available, consequently four thermometers were hung at different points among the plants and an average taken. As the greenhouse was supposed to be between $60-70^{\circ} \mathrm{F}$., the readings were taken about 2:00 P.M. each day, merely to note any marked change in temperature. It was found, however, that the variation was too great and the readings too far apart to make the data of any value 
except to show that the change from air to water was accompanied by a marked rise in temperature (fig. I). This experiment indicates that water may not be as important a factor in the growth of Scirpus validus as temperature. This is probable because the growing region is protected from the surrounding medium by a very closely fitting sheath of scale leaves.

EFFECT UPON DISTANCE BETWEEN DIAPHRAGMS.-The distance was measured between many diaphragms and the average taken. As it was found that the diaphragm distance varied with the distance from the tip, the culms were divided into decimeter sections, so that the measurements taken in corresponding sections of the different culms, and in different sections of the same culm, might be compared.

\section{TABLE III}

Distances IN mm. Between DIAPHragms of Scirpus validus grown IN WATER AND IN AIR

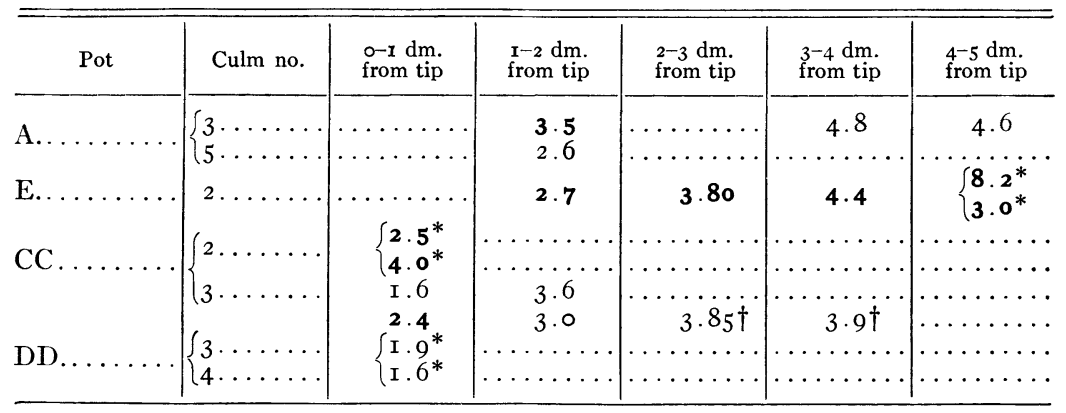

* Two chambers in same section.

$\dagger$ May extend over decimeter boundaries.

In table III the heavy type indicates parts grown in water, and the remaining figures indicate those grown in air. Read horizontally, the variation in a single culm, from tip to base, may be seen. Read vertically, the variations in the same region of the different culms are shown. As it was impracticable, from the data at hand, to calculate the rates of growth for the decimeter regions, it was not possible in this experiment to correlate the rate of growth with the distance between diaphragms.

\section{EXPERIMENT 5}

It was shown in experiment 4 that temperature control was very necessary; therefore in April rgr6 experiment 5 was set up 
in the greenhouse of the University of Chicago, using plants from the material started at the Missouri Botanical Garden in the fall.

TABLE IV

VARIATIONS IN RATE OF GROWTH AND STRUCTURE OF CULMS OF Scirpus validus UNDER DIFFERENT CONDITIONS OF MOISTURE AND HEAT

\begin{tabular}{|c|c|c|c|c|c|c|c|c|c|}
\hline Culm no. & $\begin{array}{l}\text { Region } \\
\text { (mm. from } \\
\text { tip) }\end{array}$ & $\begin{array}{c}\text { Point at } \\
\text { which } \\
\text { change } \\
\text { occurred } \\
\text { (mm. } \\
\text { from tip) }\end{array}$ & $\begin{array}{c}\text { Growth } \\
\text { (mm. per } \\
\text { day) }\end{array}$ & $\begin{array}{l}\text { No. of } \\
\text { spaces }\end{array}$ & $\begin{array}{l}\text { Layers } \\
\text { in walls }\end{array}$ & $\begin{array}{c}\text { Distance } \\
\text { between } \\
\text { dia- } \\
\text { phragms }\end{array}$ & $\begin{array}{l}\text { No. of } \\
\text { layers of } \\
\text { palisades }\end{array}$ & Medium & $\begin{array}{l}\text { Tempera- } \\
\text { ture } \\
{ }^{\circ} \mathrm{C} .\end{array}$ \\
\hline \multirow[t]{2}{*}{ E 2 . } & $\left\{\begin{array}{l}132-172 \ldots \ldots \\
\mathbf{1} 72-210 \ldots \ldots \\
210-247 \ldots \ldots\end{array}\right.$ & $\mid \begin{array}{c}\cdots \\
\cdots \cdots \cdots \\
\cdots \cdots \cdots \\
\cdots \cdots\end{array}$ & $\begin{array}{l}6.00 \\
8.33 \\
8.75\end{array}$ & \begin{tabular}{c}
$4+$ \\
$\dddot{M} \ldots \ldots \ldots$ \\
\hdashline$\ldots$
\end{tabular} & $\begin{array}{c}\mathbf{I} \\
\cdots \cdots \cdots \\
\mathbf{I}\end{array}$ & $\begin{array}{l}\text { I. } 2 \\
\text { I. } \\
2.5\end{array}$ & $\begin{array}{c}2 \\
\ldots \ldots \\
2-0\end{array}$ & Water & 35 \\
\hline & $247-290 .$. & $\begin{array}{c}247 \\
\ldots \ldots \ldots \\
\ldots \ldots \ldots\end{array}$ & $\cdots 6.14$ & Many & $\cdots \cdots$ & $3 \cdot 1$ & $\ddot{\circ}$ & Air & $\cdots_{30}$ \\
\hline \multirow[t]{2}{*}{$\mathbf{E}_{3}$} & $\left\{\begin{array}{r}50-80 \ldots \ldots \\
100-130 \ldots \\
142-172 \ldots \ldots \\
240-270 \ldots\end{array}\right.$ & $\mid \begin{array}{c}\ldots \ldots \ldots \\
\cdots \ldots \ldots \\
\cdots \ldots \ldots \\
\cdots \ldots \ldots \\
\cdots\end{array}$ & $\begin{array}{l}22.50 \\
22.00 \\
30.00 \\
70.00\end{array}$ & $\begin{array}{c}\cdots \dddot{4}+ \\
4+ \\
\cdots \cdots \cdots\end{array}$ & $\begin{array}{c}\cdots \ldots \ldots \\
\mathbf{I}-2 \\
\mathbf{I}-2 \\
\cdots \cdots \cdots\end{array}$ & $\begin{array}{l}2.8 \\
3.6 \\
3.4 \\
2.9\end{array}$ & $\left.\begin{array}{c}\ldots \ldots \ldots \\
2 \\
2 \\
\ldots \ldots \ldots\end{array}\right\}$ & Air & 30 \\
\hline & $290-320 .$. & $\begin{array}{c}205 \\
\cdots \cdots \cdots \\
\ldots \ldots\end{array}$ & 10.00 & Many & $\begin{array}{c}\cdots \cdots \cdots \\
3\end{array}$ & $\begin{array}{c}\cdots \cdots \\
3.2\end{array}$ & $\begin{array}{c}\cdots \cdots \\
\circ\end{array}$ & $\ddot{\mathrm{Air}}{ }^{\cdots}$ & $2 \mathrm{I}$ \\
\hline $\mathrm{B}_{3} \ldots \ldots$ & $\left\{\begin{array}{l}200-240 \ldots \ldots \\
260-290 \ldots \ldots \\
310-350 \ldots \\
400-450 \ldots \\
500-550 \ldots\end{array}\right.$ & 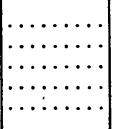 & $\begin{array}{l}18.00 \\
55.00 \\
48.00 \\
21.66 \\
20.00\end{array}$ & 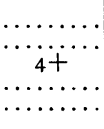 & $\begin{array}{l}\cdots \cdots \cdots \\
\cdots \\
\cdots \\
\cdots \cdots \cdots \cdots \\
\cdots \cdots \cdots \\
\mathbf{I}\end{array}$ & $\begin{array}{l}1.8 \\
2.5 \\
3.0 \\
4.1 \\
4.6\end{array}$ & $\begin{array}{c}\cdots \cdots \\
\cdots \cdots \\
2 \\
\cdots \cdots \\
\cdots \cdots \\
\cdots \cdots\end{array}$ & Water & 35 \\
\hline \multirow{3}{*}{$B_{4} \ldots \ldots$} & $\int 50-90 \ldots$ & $\cdots{ }_{96} \cdots$ & $\begin{array}{c}15 \cdot 33 \\
\ldots \ldots \ldots\end{array}$ & $\begin{array}{c}4+ \\
\ldots \ldots \ldots\end{array}$ & I & $\begin{array}{l}\text { I.4 } \\
\cdots \ldots \ldots\end{array}$ & 2 & $\begin{array}{l}\text { Water } \\
\ldots \ldots \ldots\end{array}$ & $\begin{array}{c}35 \\
\ldots \ldots\end{array}$ \\
\hline & $\left\{\begin{array}{l}105-135 \ldots \\
160-182 \ldots \\
200-240^{*} \ldots \\
260-290^{*} \ldots\end{array}\right.$ & $\begin{array}{c}\cdots \ldots \ldots \\
\cdots \cdots \\
\cdots \cdots \\
\cdots \cdots \\
304\end{array}$ & $\begin{array}{c}8.33 \\
27.00 \\
\ldots \ldots \ldots \\
29.50 \\
\ldots \ldots \ldots\end{array}$ & $\begin{array}{c}4+ \\
\ldots \ldots \ldots \\
\cdots \cdots \cdots \\
4+ \\
\ldots \ldots \ldots\end{array}$ & $\begin{array}{c}\mathbf{1} \\
\ldots \ldots \ldots \cdots \\
\cdots \ldots \ldots \cdots \\
\mathbf{I} \\
\ldots \ldots \ldots\end{array}$ & $\begin{array}{l}\text { I. } 8 \\
3.0 \\
4.2 \\
2.4 \\
\ldots \ldots\end{array}$ & $\left.\mid \begin{array}{c}\multicolumn{2}{c}{} \\
\cdots \cdots \cdots \\
\cdots \cdots \\
\mathbf{I}\end{array}\right\}$ & Water & I6 \\
\hline & $\mid \begin{array}{l}310-350 \ldots \ldots \\
400-450 \ldots\end{array}$ & $\begin{array}{c}304 \\
\cdots \cdots \cdots \\
\cdots \cdots \cdots \\
\cdots \cdots\end{array}$ & $\begin{array}{c}\cdots \cdots \cdots \\
15 . \infty \\
20.00\end{array}$ & $\begin{array}{c}\cdots \dddot{4}+\cdots \\
\cdots \cdots\end{array}$ & ${ }^{\prime} \cdots \cdots$ & $\begin{array}{l}\cdots .8 \\
2.8 \\
2.8\end{array}$ & $\left.\mid \begin{array}{c}\cdots \cdots \\
\ldots \\
\cdots \cdots\end{array}\right\}$ & Air & $\begin{array}{c}\cdots \cdots \cdots \\
\text { I6 }\end{array}$ \\
\hline \multirow{3}{*}{$\mathbf{A A}_{3} \ldots}$. & $(100-140 \ldots$ & $\cdots \operatorname{i60} \cdots$ & $17 \cdot 50$ & $4+$ & $\begin{array}{c}\mathbf{I} \\
\ldots\end{array}$ & I. 8 & $\mathbf{I}$ & Air & I6 \\
\hline & $\left\{\begin{array}{l}200-240 \ldots \ldots \\
260-300 \ldots \ldots \\
330-370^{*} \ldots\end{array}\right.$ & 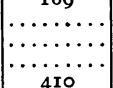 & $\begin{array}{c}\cdots \ldots .5 \\
20.50 \\
23.00 \\
23.25 \\
\ldots \ldots \ldots\end{array}$ & Many & $\begin{array}{c}\cdots \cdots \\
\cdots \cdots \cdots \\
\cdots-2\end{array}$ & $\begin{array}{l}\cdots \cdot 3 \\
2.3 \\
3.5\end{array}$ & $\cdots \cdots \cdots$ & Water & $\begin{array}{c}\cdots \cdots \\
\mathrm{I} 6\end{array}$ \\
\hline & $\mid \begin{array}{l}400-440 \ldots \\
500-540 \ldots \\
600-630 \ldots\end{array}$ & $\begin{array}{c}4 \mathrm{ro} \\
\cdots \cdots \cdots \cdots \\
\cdots \cdots \cdots \\
\cdots \cdots \cdots \\
\cdots\end{array}$ & $\begin{array}{l}\cdots \cdots \\
47.00 \\
29.00 \\
24.00\end{array}$ & $\begin{array}{l}\cdots \ldots \ldots \\
\cdots \cdots \\
\cdots \cdots \cdots \\
\cdots \cdots\end{array}$ & $\begin{array}{c}\cdots \\
\cdots \cdots \\
\cdots \cdots \\
\cdots \cdots \\
\cdots\end{array}$ & $\begin{array}{l}\cdots \\
3.0 \\
4.1 \\
4.9\end{array}$ & 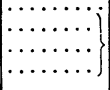 & Water & $\begin{array}{l}\cdots \cdots \\
30\end{array}$ \\
\hline \multirow[t]{3}{*}{$\mathrm{DD}_{3} \ldots$} & $\int 800-857 \ldots \ldots$ & $\cdots, \cdots$ & 13.60 & Many & $I-2-3$ & 6.1 & 0 & Water & $2 I \pm$ \\
\hline & $\mid 872-920$. & $\begin{array}{c}802 \\
\cdots \cdots \cdots \\
\cdots\end{array}$ & $\begin{array}{r}\cdots \\
7.00\end{array}$ & Many & $I-2-3$ & 6.4 & \% & $\ddot{A i r}$ & $21 \pm$ \\
\hline & (6o-rio..... & $\cdots \ldots \ldots$ & 18.00 & $\begin{array}{c}4+ \\
\ldots \ldots \ldots\end{array}$ & $I(?)$ & I. 7 & $I-2$ & Air & $21 \pm$ \\
\hline \multirow[t]{2}{*}{ DD $7 \ldots$} & $\left\{\begin{array}{l}125-175 \ldots \\
300-350 \ldots \\
400-450 * \ldots\end{array}\right.$ & $\mid \begin{array}{c}\ldots \ldots \ldots \\
\cdots \cdots \\
\cdots \cdots \\
508\end{array}$ & $\begin{array}{r}39.00 \\
33.50 \\
37.00 \\
\ldots \ldots \ldots\end{array}$ & $\begin{array}{l}4 \ddot{4}+\cdots \\
\text { Many }\end{array}$ & $\begin{array}{c}I(?) \\
I-2 \\
\cdots \cdots \cdots\end{array}$ & $\begin{array}{l}1.7 \\
1.7 \\
3.5 \\
3.0 \\
\cdots . .\end{array}$ & $\left.\begin{array}{c}2 \\
2 \\
\ldots \ldots \ldots\end{array}\right\}$ & Water & $2 I \pm$ \\
\hline & $\left(51_{5}-565 \ldots\right.$ & $\begin{array}{c}508 \\
\ldots \ldots \ldots\end{array}$ & 16.66 & Many & $\mathrm{I}-2-3$ & $\ddot{3} \cdot \ddot{4}$ & $\ddot{2}$ & Water & $\ddot{1}^{\prime} \cdots$ \\
\hline \multirow[t]{2}{*}{ DD $8 \ldots$} & $\left\{\begin{array}{r}44-74 \ldots \\
\text { roo-r } 50 * \ldots\end{array}\right.$ & $\begin{array}{l}\cdots \cdots \cdots \\
\cdots{ }_{162}\end{array}$ & $\begin{array}{r}9.00 \\
21.50\end{array}$ & $\begin{array}{l}4+ \\
4+\end{array}$ & $\begin{array}{c}\mathbf{I} \\
\mathbf{I}-2-3\end{array}$ & $\begin{array}{l}\text { I.7 } \\
2.2\end{array}$ & $\begin{array}{l}2 \\
2\end{array}$ & Water & $22 \pm$ \\
\hline & $200-250 .$. & $\ldots \ldots \ldots$ & 18.66 & $4+$ & I & 2.7 & 2 & Water & ${ }^{16}{ }^{\cdots}$ \\
\hline
\end{tabular}

* Not observed for a period of 4 days.

$\dagger$ Distance between diaphragms in $\mathrm{mm}$.

$\ddagger$ "Many" indicates a number of fairly equal-sized spaces in contrast with 4 large spaces and several small ones.

This content downloaded from 080.082.077.083 on February 19, 2018 19:20:37 PM All use subject to University of Chicago Press Terms and Conditions (http://www.journals.uchicago.edu/t-and 
The thermostats were kindly loaned by the Chemistry Department, and were regulated by Captain de Klotinski. The higher temperature vessel was kept within a degree of $35^{\circ} \mathrm{C}$. for two weeks, and for the remainder of the experiment practically at $3 \mathrm{I}^{\circ} \mathrm{C}$. In the low temperature vessel a coil of pipe, carrying a stream of cold water, kept the temperature close to $15^{\circ} \mathrm{C}$. for the first two weeks, and for the rest of the time about $16^{\circ} \mathrm{C}$. The temperature in this vessel was not quite so constant as in the higher temperature thermostat, because of the varying water pressure. A third set of plants was allowed to grow without temperature control. When the change to air was made, the pots were transferred to beakers

TABLE $\mathrm{V}$

RELATION BETWEEN RATE OF GROWTH AND DISTANCE BETWEEN DIAPHRAGMS IN Scirpus validus

\begin{tabular}{|c|c|c|c|}
\hline Change & Culm no. & Rate & Distance \\
\hline Water to air........ & $\left\{\begin{array}{r}\text { E } 2 \\
\text { B } 4 \\
\text { DD } 3\end{array}\right.$ & $\begin{array}{l}\text { Decreased } \\
\text { Decreased } \\
\text { Decreased }\end{array}$ & $\begin{array}{l}\text { Increased } \\
\text { Increased } \\
\text { Increased }\end{array}$ \\
\hline Air to water... & $\left\{\begin{array}{l}\mathrm{AA}_{3} \\
\mathrm{DD} 7\end{array}\right.$ & $\begin{array}{l}\text { Increased } \\
\text { Increased }\end{array}$ & $\begin{array}{l}\text { Increased } \\
\text { Increased }\end{array}$ \\
\hline Low to high temperature.......... & $\mathrm{AA}_{3}$ & Increased & Decreased \\
\hline High to low temperature.. & $\left\{\begin{array}{r}\mathrm{E}_{3} \\
\mathrm{~B} 4 \\
\mathrm{DD} \\
\\
8\end{array}\right.$ & $\begin{array}{l}\text { Increased } \\
\text { Decreased } \\
\text { Decreased } \\
\text { Decreased }\end{array}$ & $\begin{array}{l}\text { Decreased } \\
\text { Increased } \\
\text { Increased } \\
\text { Increased }\end{array}$ \\
\hline
\end{tabular}

sunken to the rim in the water of the thermostats. Water was poured into the beakers to within an inch of the surface of the soil. The tops were covered with two pieces of glass, allowing the culms to project between them, and the crack was plugged with cotton wool. Close observation showed the temperature in the beakers to be practically the same as that of the water outside. Measurements were taken every 24 hours, and the rate of growth given for a region was usually the average for several days, thus eliminating the questioned stimulating effect of the change ( $\mathbf{r}, \mathbf{9}$, I0, 14). At the end of the experiment longitudinal and cross sections were made in the regions grown under the different conditions. The cross-sections were usually made at one end of a region 
and the rest cut longitudinally, and therefore the results given in table IV are obviously not for exactly the same spot.

The number of changes was insufficient for reliable conclusions; also it must be remembered that under normal conditions there is a general tendency for the distance between diaphragms to increase from tip to base (see also $\mathrm{B} 3$ ). Certain indications, however, are summarized in table $\mathrm{V}$.

\section{Discussion AND CONCLUSION}

GRowtH.-Region.-So far I have found no reference to the region of growth in the stem of Scirpus. Pfeffer (Io) refers to the basal region of growth in the leaves of Canna and Tulipa and in the internodes of grasses, and states that the "length of the zone is always small." He also mentions the careful protection of this zone. The same statements may be made for the zone of growth in the Scirpus stem; the extreme narrowness of the zone, however, is rather surprising. Growth in diameter was not studied.

Rate.-The results of the experiments were not perfectly harmonious; but in general there seemed to be a tendency toward an increase in rate with a change from air to water, and a decrease with the reverse change. It seems probable, however, that temperature was a more important factor than water.

Diaphragm distance.-From a study of table III it is evident that the variation between culms growing under the same conditions was greater than that between culms growing under different conditions of air and water, thus eliminating water as a direct factor in determining the distance between diaphragms. Its indirect effect was studied in experiment 5 , and although the data were too scanty for positive statements, certain facts are rather significant. As there is a normal tendency for the diaphragm distance to increase from tip to base, the cases of increase after a change in environment may not be significant. Two cases of decrease occurred, however; one accompanying a change from high to low temperature, and the other following the reverse change. This would eliminate the temperature change as the direct factor. The fact that both of the cases of decrease in distance were associated with an increased growth rate is the important point. Also, 
of the 29 cases of a change in rate of growth and diaphragm distance shown in table IV, I9 (64 per cent) showed an inverse relation between the two; 9 (24 per cent) showed a direct relation; and in 3 cases (Io per cent) an equal distance went with an increased rate. When we remember that the normal tendency is to increase the distance from tip to base, these last three cases really show an inverse relation which, added to the I9 preceding, make 22 (75 per cent) which show an inverse relation. Of these, I4 (49 per cent of total) show an increase downward, which coincides with the normal tendency, while 8 (27 per cent of total) show a decrease downward in opposition to the normal tendency, and therefore the more significant. These confirm the indication shown by the 49 per cent, and tend to establish an inverse relation between rate of growth and distance between diaphragms.

This is not what one would expect if the distance between diaphragms is considered to be brought about by the excessive growth, or stretching, of the intervening tissues. It is what one would expect, however, if, as was suggested in a former paper (13), diaphragms are due to certain cells retaining their power of division and growth, while those above and below them lose this power and are drawn out into arachnoid cells by the growth of the surrounding tissues; and also if the formative activities show a gradient from beginning to end of the growth of the stem. This suggests several interesting questions. Is there such a formative gradient? Would the respiration test show a gradual decline in metabolic changes, or would it follow the growth curve? Is it possible that, in averaging the diaphragm distances in a region, a shortening, corresponding to the rise in the growth curve, was overlooked? Is the peak of the growth curve due wholly to a stretching period? If so, would this stretching counterbalance the tendency to shorten the diaphragm distance with the rise in the growth curve?

AIR CHAMBers.-Scirpus validus appears to start with four large chambers and a number of small ones. As the culm grows, the small ones increase in size, until many nearly equal-sized spaces are the result. The different culms may pass through these stages at different rates; therefore the same regions cannot be compared. Only two cases were noted in which a rather rapid 
increase in the number of spaces occurred; in one, following a change from air to water, there was a marked increase within a distance of $\mathrm{I}_{5} \mathrm{~mm}$; in the other a noticeable increase occurred within $9 \mathrm{~mm}$., following a change from low to high temperature. From these experiments there is no clear evidence that either water, temperature, or rate of growth has any effect upon the number or size of chambers produced.

Partitions BetWeEN AIR CHAMBers AND OUTER WALL OF STEM. -The changes in environment used in these experiments appear to have no effect upon the regular course of development of the partitions, which seems to be an increase in the number of layers from one to three. No observable difference could be noted in the outer wall of the stems.

PALISADE LAYERS.-The curious banding, which is sometimes seen in Scirpus, occurred in experiment 5. The albescent spaces and the basal region contained no palisades. The dark green portions contained two layers of palisades, and the pale green spaces one layer, or two with only part of the cells chlorophyllous. The environmental changes in the experiment seem to have no effect upon the development of palisades, and cannot be held responsible for the banded appearance.

\section{Reduced atmospheric pressure}

\section{EXPERIMENTS}

During February I9I6 a series of experiments was started in the temperate house of the University of Chicago, to test the effect of low atmospheric pressure upon the air chambers of water plants. The apparatus is shown in fig. 2 and described in the legend. The temperature of the house was controlled by the general heating system, and a recording thermometer showed a variation of a degree about $20-2 \mathrm{I}^{\circ} \mathrm{C}$. The barometric pressure was obtained in experiment I from the records of a government instrument outside the greenhouse, and the figures were reduced to metric readings at $2 \mathrm{I}^{\circ} \mathrm{C}$. In experiments 2 and 3 the pressure readings were obtained from the barometer in the Botany Building, and corrected for temperature only. The pressure in the experimental 
jar was read on the manometer. It varied somewhat on account of the variation in the flow of the city water supply used to produce the suction. Plants of Scirpus validus, selected from those started in St. Louis, and Cyperus alternifolius (?), already growing in the greenhouse, were used.

\section{EXPERIMENT I}

This extended February $4^{-1} 4$. The pressure varied between Io and $20 \mathrm{~mm}$. of mercury. This pressure was chosen because air

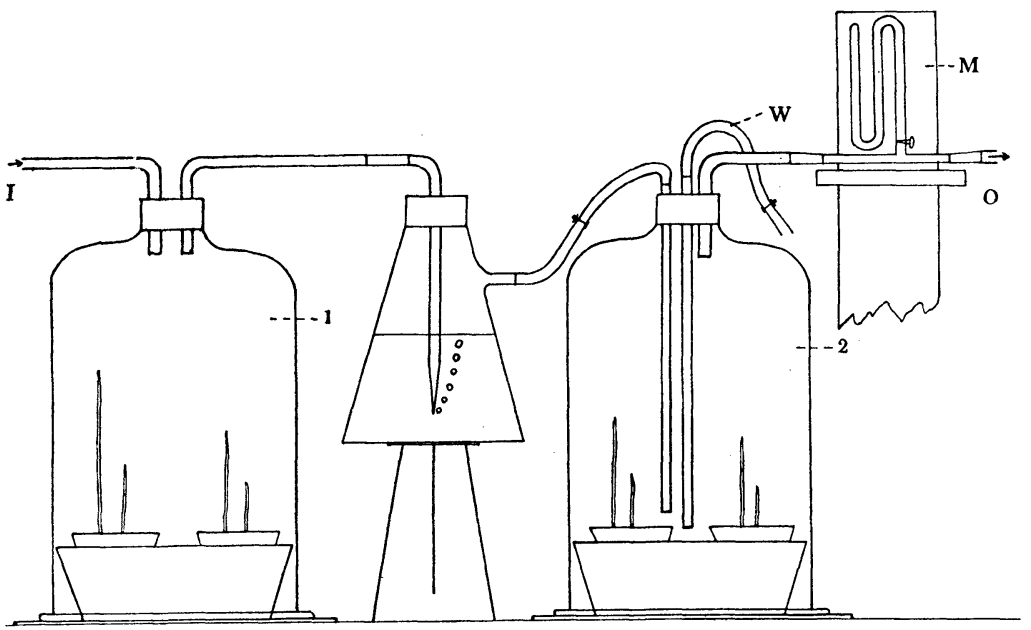

FIG. 2.-Apparatus to test effect of low atmospheric pressure: bell-jar I, control; bell-jar 2, experiment; under each jar a pan of water containing pots of Scirpus; air entering at $I$ and also around bottom of I (not sealed as was 2) passed out of I into flask where narrowed tube retarded flow and bubbles indicated rapidity of passage; in 2 air entered at bottom and escaped at top, thence through two catch bottles to pump operated by city water supply; $m$, manometer; $w$, tube for watering 2 .

at $20 \mathrm{~mm}$. pressure contains about as much oxygen as is dissolved in water (8). Cyperus would not grow at this pressure, and Scirpus alone was used. The culms were measured twice a day, and, after the close of the experiment, longitudinal and cross sections were made and measurements taken as in the previous experiments. Culms nos. I and 2 belonged to the control plant, nos. 3 and 4 to the experimental plant. Fig. 3 and tables VI and VII give the 
results obtained. In fig. 3 the peak in the pressure curve at $5: 30$ (February 7) was due to the fact that the pinch-cocks were left open for a short time during watering. The second peak

TABLE VI

Growth AND StRUCture of Scirpus validus: CULMS I AND 2 GROWN AT ATMOSPHERIC PRESSURE; CULMS 3 AND 4 GROWN AT IO-2O MM. PRESSURE

\begin{tabular}{|c|c|c|c|c|c|c|c|c|}
\hline \multirow{2}{*}{ Culm no. } & \multirow{2}{*}{ REGION } & \multirow{2}{*}{$\begin{array}{l}\text { DIAMETER } \\
\text { IN MM. }\end{array}$} & \multicolumn{2}{|c|}{ WALLS IN MM. } & \multicolumn{2}{|c|}{ Spaces } & \multirow{2}{*}{$\begin{array}{l}\text { DIAPHRAGM } \\
\text { DISTANCE } \\
\text { IN MN. }\end{array}$} & \multirow{2}{*}{$\begin{array}{c}\text { GROWTH } \\
\text { (MM. PER } \\
\text { HOUR) }\end{array}$} \\
\hline & & & Outer & Inner & Large & Small & & \\
\hline I. & $45-7 I$ & & & & & & & \\
\hline 2. & $45-7 x$ & 2.00 & o. I68 & 0.050 & 4 & 6 & $2 \cdot 36$ & $0.5 \mathrm{I}$ \\
\hline $3 \ldots$ & $45^{-71}$ & $\ldots \ldots$ & $\ldots \ldots \ldots$ & $\ldots \ldots$ & . & & $\ldots \ldots$ & $\ldots$ \\
\hline $4 \ldots$ & $45-7 \mathrm{I}$ & I. 57 & o. I34 & 0.054 & 4 & 8 & $3.9^{2}$ & $0.3^{2}$ \\
\hline I. & $7 \mathrm{I}-100$ & & & & & & & \\
\hline $2 \ldots$ & $71-100$ & I. 89 & 0.156 & 0.050 & 4 & IO & $2 \cdot 55$ & 0.85 \\
\hline $3 \ldots$ & $71-100$ & 2.25 & 0.103 & 0.060 & I5 & 9 & $3 \cdot 5^{\circ}$ & 0.53 \\
\hline 4. & $71-100$ & I. 58 & O. II9 & $0.05^{2}$ & 7 & 9 & 4.05 & 0.49 \\
\hline I. . & $100-124$ & & & & & & & \\
\hline 2 . & $100-124$ & 2.15 & 0. 108 & 0.050 & 7 & 8 & 3.19 & I. 35 \\
\hline 3 . & $100-124$ & $2 \cdot 38$ & $0.15^{\circ}$ & 0.050 & I5 & 7 & 5.60 & $0.5 \mathrm{I}$ \\
\hline $4 \cdots$ & $100-124$ & I . 73 & 0. 103 & 0.090 & I 2 & 7 & 3.90 & $0.2 \mathrm{I}$ \\
\hline I. & I $24-175$ & 2.50 & 0.050 & 0.065 & I 7 & I6 & 6.08 & \\
\hline $2 \ldots$ & I $24-\mathrm{I} 75$ & 2.25 & O. 128 & 0.070 & 7 & 9 & 3.73 & I. 39 \\
\hline $3 \cdots$ & I $24-\mathrm{I} 75$ & $2 \cdot 50$ & O.II3 & 0.090 & I6 & 7 & 5.18 & 0.36 \\
\hline
\end{tabular}

TABLE VII

INCREASE IN DIAPHRAGM DISTANCE IN MM.

\begin{tabular}{|c|c|c|}
\hline Region & No. 4 over no. 2 & No. 3 over no. 2 \\
\hline $45^{-71} \ldots \ldots \cdots \cdots$ & 0.56 & $\cdots \cdots \cdots \cdots$ \\
\hline 7 I-100 $\ldots \ldots \ldots \ldots$ & I. 50 & 0.95 \\
\hline IOO-I $24 \ldots \ldots \ldots \ldots$ & $0.7 \mathrm{I}$ & $2.4 \mathrm{I}$ \\
\hline I $24-$ I $75 \ldots \ldots \ldots$ & $\ldots \ldots \ldots \ldots$ & I 45 \\
\hline
\end{tabular}

cannot be definitely accounted for by the data at hand. It is very probable that in these two cases, as well as in two others, an adjustment was made at once, but there are no records of the fact, such as occur later. The dotted line, therefore, is probably the more correct one. 


\section{EXPERIMENT 2}

This experiment extended February 14-28. It was set up in the same apparatus as was experiment I; the pressure, however, started at $35 \mathrm{~mm}$. and varied between 20 and $40 \mathrm{~mm}$. of mercury. Cyperus would not grow at this pressure; consequently the results

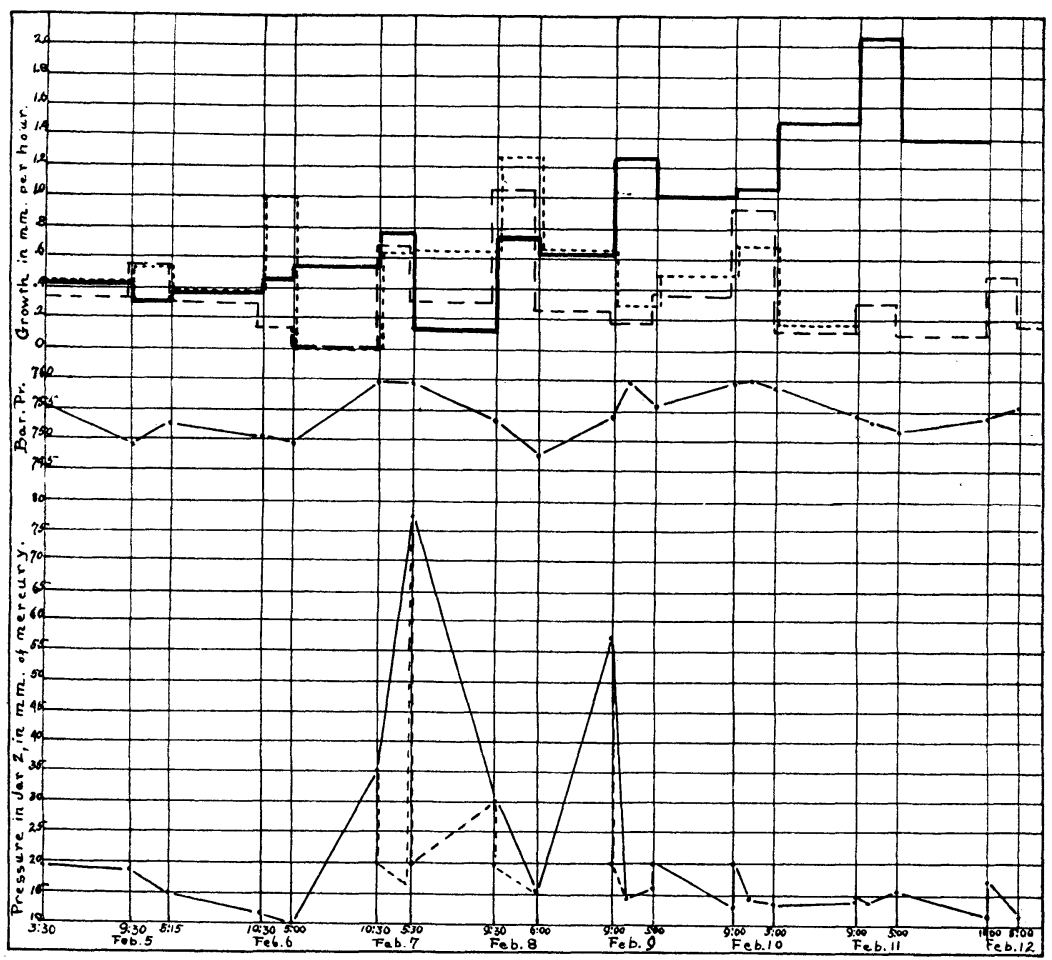

FIG. 3.- Growth curves: solid line, no. 2; dotted line, no. 3; broken line, no. 4; curves 2 and 3 cease when culms reached top of jar.

are given for Scirpus only. The quantity of air passing through the jars was measured and found to be about I 500-2 100 cc. per hour. At times it exceeded this amount, but the flow was kept fairly constant. The experimental culms were nos. 3 and 4 , and the controls nos. I and 2. Tables VIII and IX give the results. 
TABLE VIII

Growth AND STRUCTURE OF Scirpus validus: CULMS I AND 2 GROWN AT ATMOSPHERIC PRESSURE; CULMS 3 AND 4 GROWN AT 20-40 MM. PRESSURE

\begin{tabular}{|c|c|c|c|c|c|c|c|c|}
\hline \multirow{2}{*}{ Culm no. } & \multirow{2}{*}{ REgION } & \multirow{2}{*}{$\begin{array}{l}\text { DIAMETER } \\
\text { IN MM. }\end{array}$} & \multicolumn{2}{|c|}{ WALLS IN MM. } & \multicolumn{2}{|c|}{ Spaces } & \multirow{2}{*}{\begin{tabular}{|} 
DIAPHRAGM \\
DISTANCE \\
IN MM.
\end{tabular}} & \multirow{2}{*}{$\begin{array}{c}\text { GROWTH } \\
\text { (MM. PER } \\
\text { HOUR) }\end{array}$} \\
\hline & & & Outer & Inner & Large & Small & & \\
\hline I ..... & $0-10$ & 0.885 & 0.14 & 0.05 & 3 & 5 & $\ldots \ldots$ & $\ldots \ldots$ \\
\hline $2 * \ldots \ldots$ & $0-$ IO & 0.895 & O.II & 0.04 & 4 & 5 & $\ldots \ldots \ldots$ & $\ldots \ldots$ \\
\hline $3 \ldots \ldots$ & $0-$ IO & 0.910 & O. I I & 0.05 & 2 & 2 & $\ldots \ldots \ldots$ & $\ldots \ldots \ldots$ \\
\hline $4 \ldots \ldots$ & $0-10$ & I.OIO & 0.08 & 0.05 & 4 & 6 & $\ldots \ldots$ & $\ldots \ldots$ \\
\hline I . . & $10-30$ & I. 260 & O. I 7 & 0.03 & 4 & 4 & I. 630 & 0.48 \\
\hline $2^{*} \ldots \ldots$ & $10-30$ & I. 775 & O. I4 & 0.04 & 4 & 9 & 0.085 & $\ldots \ldots \ldots$ \\
\hline $3 \ldots \ldots$ & $10-30$ & I. 545 & o. I3 & 0.05 & 4 & 7 & 2.170 & 0.37 \\
\hline $4 \ldots \ldots$ & $10-30$ & I. 550 & O.I4 & 0.06 & 5 & I I & 3.100 & 0.24 \\
\hline $\mathbf{I} \ldots \ldots$ & $30-65$ & I. $45^{\circ}$ & o. I 8 & 0.09 & 4 & 8 & I. $75^{\circ}$ & 0.68 \\
\hline $2^{*} \ldots$ & $30-65$ & I. 830 & O. I 5 & 0.06 & I 2 & 9 & 2.150 & $\ldots \ldots$ \\
\hline $3 \ldots \ldots$ & $30-65$ & I. 9IO & O. I4 & 0.05 & 4 & 8 & 3.400 & 0.55 \\
\hline $4 \ldots \ldots$ & $30-65$ & I . 800 & O.I3 & 0.05 & 5 & I4 & 2.950 & 0.49 \\
\hline I $\ldots$ & $65-105$ & I. 600 & 0.14 & $\ldots \ldots$ & 4 & 8 & $2 \cdot 320$ & 0.83 \\
\hline $2 * \ldots$ & $65-105$ & 2.000 & 0.12 & 0.06 & I6 & IO & 2.030 & $\ldots \ldots \ldots$ \\
\hline $3 \ldots \ldots$ & $65-105$ & 2.155 & ㅇ. I 5 & 0.07 & 4 & I5 & 2.980 & 0.57 \\
\hline $4 \ldots \ldots$ & $65-105$ & 2.050 & O.I3 & 0.09 & 5 & I6 & 3.180 & 0.47 \\
\hline I $\ldots \ldots$ & $105^{-1} 30$ & $\ldots \ldots \ldots$ & $\ldots \ldots \ldots$ & $\ldots \ldots \ldots$ & $\cdots$ & $\ldots \ldots$ & $\ldots \ldots$ & $\ldots \ldots \ldots$ \\
\hline $2 \ldots \ldots$ & $105^{-1} 30$ & I. 940 & o. I3 & 0.05 & I 8 & IO & 2.300 & $\ldots \ldots \ldots$ \\
\hline $3 \ldots \ldots$ & $105^{-1} 30$ & 2.255 & O.I 5 & 0.08 & 4 & I 5 & 3.270 & 0.83 \\
\hline $4 \ldots \ldots$ & $105^{-1} 30$ & I. 875 & O.I I & 0.07 & I I & 12 & $3 \cdot 480$ & 0.95 \\
\hline
\end{tabular}

* Culm 2 grew rro mm., before the experiment, under practically the same conditions as the control; the measurements are used with this fact in mind.

TABLE IX

INCREASE IN DIAPHRAGM DISTANCE IN MM.

\begin{tabular}{|c|c|c|c|}
\hline Region & No. 3 over no. I & No. 3 over no. 2 & No. 4 over no. 2 \\
\hline $\begin{array}{r}\text { 10- } 30 \ldots \ldots \ldots \ldots \\
30-6_{5} \ldots \ldots \ldots \ldots \ldots \\
65^{-10} \ldots \ldots \ldots \ldots \ldots \\
\text { 105-1 } 30 \ldots \ldots \ldots \ldots \ldots\end{array}$ & $\begin{array}{c}0.54 \\
1.65 \\
0.66 \\
\ldots \ldots \ldots .\end{array}$ & $\begin{array}{l}2.085 \\
\text { I. } 250 \\
0.950 \\
0.970\end{array}$ & $\begin{array}{l}3.015 \\
0.800 \\
\text { I. I50 } \\
\text { I. . } 180\end{array}$ \\
\hline
\end{tabular}

\section{EXPERIMENT 3}

This experiment was set up on February 28 under the same conditions as experiments I and 2, except for the pressure, which was kept between 60 and $80 \mathrm{~mm}$. of mercury. The experiment was discontinued on March 4 because the culms had reached the top of the jars. At the end of the experiment the manometer 
showed a trace of moisture, and was found, upon being tested with the air pump, to register $2 \mathrm{~mm}$. too low. As the variation in pressure had been $20 \mathrm{~mm}$., it was not thought necessary to correct

\section{TABLE X}

GROWTH AND STRUCTURE OF Scirpus validus: CULM I GROWN UNDER ATMOSPHERIC PRESSURE; CULM 2 GROWN UNDER 60-80 MM. PRESSURE

\begin{tabular}{|c|c|c|c|c|c|c|c|c|}
\hline \multirow{2}{*}{ Culm no. } & \multirow{2}{*}{ REGION } & \multirow{2}{*}{$\begin{array}{l}\text { DIAMETER } \\
\text { IN MM. }\end{array}$} & \multicolumn{2}{|c|}{ WALLS IN MM. } & \multicolumn{2}{|c|}{ Spaces } & \multirow{2}{*}{$\begin{array}{c}\text { DIAPHRAGM } \\
\text { DISTANCE } \\
\text { IN MM. }\end{array}$} & \multirow{2}{*}{$\begin{array}{c}\text { GROWTH } \\
\text { (MM. PER } \\
\text { HOUR) }\end{array}$} \\
\hline & & & Outer & Inner & Large & Small & & \\
\hline I. . & $95^{-1} 35$ & I. 85 & 0.130 & 0.058 & 7 & I 7 & 2.50 & 0.62 \\
\hline 2. & $95^{-1} 35$ & I. 79 & 0.123 & & 4 & I 5 & 2.36 & $0.5^{2}$ \\
\hline I. & I $35^{-1} 73$ & I. 86 & 0.133 & 0.065 & I 2 & I 2 & $2.4 \mathrm{I}$ & 0.80 \\
\hline 2 . & $\mathrm{I} 35^{-\mathrm{I}} 73$ & I. 95 & o.I35 & 0.082 & 7 & I 5 & 2.29 & 0.89 \\
\hline
\end{tabular}

TABLE XI

INCREASE IN DIAPHRAGM DISTANCE IN MM.

\begin{tabular}{c|c}
\hline \hline Region & No. r over no. 2 \\
\hline $30-59^{*}$ & 0.39 \\
$95^{-1} 35$ & 0.19 \\
I $35^{-1} 73$ & 0.12 \\
\hline
\end{tabular}

* Before the experiment.

TABLE XII

Diaphragm Distance AND RATE of GROWTH of Scirpus validus UNDER REDUCED ATMOSPHERIC PRESSURE

\begin{tabular}{|c|c|c|c|}
\hline Experiment no. & Culm no. & $\begin{array}{c}\text { Average distance } \\
\text { between diaphragms } \\
\text { in } \mathrm{mm} \text {. }\end{array}$ & $\begin{array}{l}\text { Average growth rate } \\
\text { in } \mathrm{mm} \text {. per hour }\end{array}$ \\
\hline I $\ldots \ldots \ldots$ & $\left\{\begin{array}{l}2^{*} \ldots \ldots \ldots \\
3 \ldots \ldots \ldots \\
4 \ldots \ldots \ldots\end{array}\right.$ & $\begin{array}{l}2.96^{*} \\
4.76 \\
3.96\end{array}$ & $\begin{array}{l}\text { I. } 02 * \\
0.43 \\
0.3^{2}\end{array}$ \\
\hline II. . . . . . . & $\left\{\begin{array}{l}\mathrm{I}^{*} \ldots \ldots \ldots \\
3 \ldots \ldots \ldots \\
4 \ldots \ldots \ldots\end{array}\right.$ & $\begin{array}{l}\text { I. } 90^{*} \\
2.96 \\
3.18\end{array}$ & $\begin{array}{l}0.84^{*} \\
0.62 \\
0.44\end{array}$ \\
\hline III . . . . & $\left\{\begin{array}{l}I^{*} \ldots \ldots \ldots \\
2 \ldots \ldots \ldots\end{array}\right.$ & $\begin{array}{l}2.46^{*} \\
2.33\end{array}$ & $\begin{array}{l}0.70 * \\
0.68\end{array}$ \\
\hline
\end{tabular}

* Control culms grown under greenhouse conditions.

for this error. On the average 5 liters of air passed through the apparatus per hour. Culm I was the control and culm 2 the experimental one. Tables X, XI, and XII give the results. 
Experiment 3 consisted of only two culms; therefore the disagreement found in the other experiments between the culms in the same pot is not noticed here.

\section{DISCUSSION AND CONCLUSIONS}

ATMOSPHERIC PRESSURE AND GROWTH.-Much work, with conflicting results, has been done upon the effect of varying degrees of atmospheric pressure upon growth. There is a rather general agreement that a certain decrease in pressure accelerates growth, but a difference of opinion as to whether this is due directly to diminished pressure or to a decrease in the partial pressure of the oxygen (8, II, I5), also whether increased growth in water is due to decreased oxygen pressure or to some other factor.

Low pressure (10-20 $\mathrm{mm}$. in experiment $\mathrm{I}$ ) seemed to have a general depressing effect upon growth in Scirpus, as will be seen in fig. 3 and table XII. The curve shows that this effect was not constant, however, and that growth did not follow the variations in pressure. In general there is greater growth in both control and experiment during the day. The graphs for experiments 2 and 3 show this last point somewhat more clearly, and also show the closer agreement of the two curves as the pressure in the experiment was increased, but they are not sufficiently striking to merit inclusion in this report. The power to grow fairly well with such a small supply of oxygen evidently enables Scirpus to grow in very poorly aerated situations.

DIAPHRAGM DISTANCE.-If low atmospheric pressure had any effect upon distance between diaphragms, there would be a progressive increase, or decrease, in the experimental culms as compared with the control, because there is a normal tendency to increase the distance from tip to base. Tables VII and IX show that, while the experimental culms had a greater diaphragm distance throughout than the control, this did not increase progressively, but varied in the different regions. In experiment 3 , however, the results were different. Before the experiment the control had the greater diaphragm distance (I.6I-I.22 mm.). This persisted, but in a diminishing amount (table XI), which really means a progressive increase in the experimental culm. It is 
possible that the greater diaphragm distance found in the experimental culms may have been due only indirectly to decreased pressure, through its effect upon growth. In every instance (except region $95^{-1} 35$, experiment 3 ) an increase in the diaphragm distance was correlated with decreased growth rate. This agrees with the results reported earlier in this paper.

NuMBER OF AIR CHAMBERS.- - In reviewing the literature one finds a rather general opinion that air spaces increase with the amount of water in the substratum $(2,3,7$, ro, 12, r6). Recent work by Folsom (6) on Ranunculus, however, has shown that while the aerenchyma of the stem varied directly with the amount of water in the soil, that of the root showed no such constant relation, and in some cases even varied inversely. Various functions have been attributed to the air-containing tissue by different authors. Some consider it as "floating tissue" (2, 9, ro), while others consider it a means of oxygen supply, giving a lack of oxygen as its direct cause $(\mathbf{7}, \mathbf{1 0}, \mathbf{1 2})$. On the other hand, WIELER thinks it has no function, and attributes its formation to the direct stimulus of water contact. Devaux (5) thinks that the hypertrophy of lenticels found in water and moist air is due to a checking of the transpiration, a factor which apparently has not been tested in connection with the formation of air spaces, although suggested some time ago by Cowles (4).

If low oxygen pressure is 'the cause of increased air spaces, it is rather strange that in Folsom's experiments the roots, which under any condition are farther from the oxygen supply than the stem, should show either inconstant increase or a positive decrease in aerenchyma with increase in water content of the soil. In experiment 3 there was a small increase in the total number of air chambers in the experimental culm, at the same time that the control remained the same. On the other hand, experiments I and 2 give evidence of a greater variation in total number of spaces and in their uniformity in size between the culms under like conditions than between the experiment and the control. Contrary to expectation, therefore, low atmospheric pressure appears to have no effect upon these two characters in Scirpus. 
INNER AND OUTER WALLS. - The records show a close similarity in the width of the outer solid tissue of the culms of the control and of the experiment. This is also true for the partitions between the chambers.

Palisades. - In experiment $\mathrm{I}$, one control culm developed one layer of palisades and the other two; while in experiment 2 the same thing occurred in the experimental culms. In the third experiment both culms had two layers. Atmospheric pressure seems therefore to have no effect upon palisade tissue.

\section{EXPERIMENT 4}

This experiment extended from April i I to May ro. The apparatus used was the same as in the previous experiments, except that a tube dipping into a dish of mercury was used to indicate the pressure instead of the regular manometer. Cyperus alternifolius (?) was used in this and the following experiment instead of Scirpus. The time was divided into five periods, during which an effort was made to keep the pressure at $\mathrm{I} / 6$

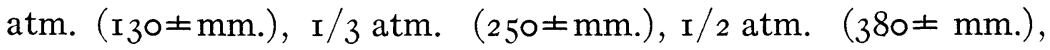
$3 / 4 \mathrm{~atm}$. (570 $\pm \mathrm{mm}$.), and $5 / 6 \mathrm{~atm}$. (630 $\pm \mathrm{mm}$.) respectively. The pressure varied very greatly, probably because the city water supply varied more at this time than earlier in the year. Culms I, 2, 6, 7, and 8 were the control, and nos. 3, 4, 5, and 9 the experimental culms. Nos. I, 2, 3, and 4 started before the experiment and were not used in the comparison. Culms 3 and 4 when placed at I/6 atm. grew very little and ceased growth in $3^{-4}$ days. At the end of a week the pressure was raised to $1 / 3$ atm., but without effect upon these culms. Toward the end of this period no. 5 started to grow slowly. At the same time no. 6 started in the control. With the rise to I/ 2 atm. no. 5 grew better, but still kept behind no. 6 . The rates approached each other very closely when the pressure rose to $3 / 4 \mathrm{~atm}$. During this period no. 7 began to grow in the control, and as it followed very closely the growth curve of no. 6 (which had grown very tall) it was used for comparison with no. 5. At $5 / 6$ atm. no. 7 still maintained a higher rate than no. 5 , which by this time had about reached the limit of its growth. About the middle of this period no. 8 started in the control, and no. 9 
in the experiment, and the graphs for nos. 7, 8, and 9 are so nearly alike that it is evident that this amount of pressure has the same effect on the growth of Cyperus as full atmospheric pressure.

After the experiment was over, cross-sections were made at the same distances from the top in the two sets of culms, but no evidence that diminished pressure had any effect upon the air spaces could be observed.

\section{EXPERIMENT 5}

This experiment was set up May ro, using the same apparatus as in the last experiment. The pressure was kept for 3 days at about $\mathrm{I} / 2 \mathrm{~atm}$. (380 $\mathrm{mm}$.) and for 2 weeks at about $7 /$ Io atm.

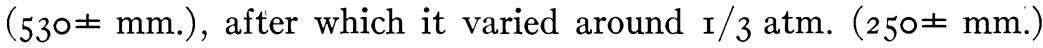
for 6 days. Growth was not measured, but after May 3I crosssections were made. A careful study of these show that at $30 \mathrm{~mm}$. from the base the experimental culm was a little more lacunose than the control, at $50 \mathrm{~mm}$. still more so, but at $70 \mathrm{~mm}$. it showed less difference. At $95 \mathrm{~mm}$. the experimental culm ended in the usual tuft of leaves, while the control grew much higher, and at $95 \mathrm{~mm}$. showed a structure exactly like that of the experimental culm at 50 or $70 \mathrm{~mm}$. The shorter culm evidently had not differentiated as much as the longer one, and the difference in the sections was therefore only apparent and not due to the effect of diminished pressure.

From these two experiments one must conclude that, although atmospheric pressure reduced below $630 \pm \mathrm{mm}$. had a retarding effect upon the growth of Cyperus, there is no evidence that it had any effect upon the air spaces.

\section{Summary}

I. The zone of growth of Scirpus validus is very short, possibly 2-3 $\mathrm{mm}$.

2. The direct contact of the surrounding medium with the growing region is prevented by a closely fitting sheath of scale leaves.

3. In these experiments the rate of growth, in general, was increased by a change from air to water, and from low to high 
temperature; while the reverse changes resulted in a decrease in the rate.

4. Temperature seemed to be a more important factor than water.

5. The increase in diaphragm distance which followed a change from water to air, and from high to low temperature, did not seem to be sufficiently great to be considered a direct result of the change, inasmuch as there is a normal tendency to increase from tip to base.

6. There appeared to be an inverse relation between diaphragm distance and rate of growth.

7. Environmental conditions may influence diaphragm distance by their effect upon growth.

8. A decreased growth rate would indicate a lowering of the vital activities of the plant, and would result in the formation of fewer diaphragms, thus increasing the distance between them.

9. This decreased vitality was shown normally in the decrease in growth rate toward the close of the growth period, and was accompanied by an increase in diaphragm distance.

Io. This plant grew fairly well under 10-20 $\mathrm{mm}$. pressure, while under $60-80 \mathrm{~mm}$. pressure there was almost as good growth as under normal pressure.

I I. There appeared to be an increase in diaphragm distance at low pressures. Apparently this was due to the retarding effect of diminished pressure upon growth.

I2. Lowered pressure appeared to have no effect upon (I) the total number of air chambers or their size, (2) the thickness of the mass of tissue on the outside of the stem or of the partitions between the chambers, and (3) the number of palisade layers.

13. These experiments lead one to conclude either that water with its low oxygen content is not the direct cause of the air spaces in aquatics, or that Scirpus validus is a very non-plastic organism, retaining its characteristic growth and structure under wide variations in environmental conditions.

I4. A lowering of the atmospheric pressure below $630 \pm \mathrm{mm}$. had a retarding effect upon the growth of Cyperus alternifolius (?), but there is no evidence that it had any effect upon the air spaces.

Wellestey College

Wellesley, Mass. 


\section{LITERATURE CITED}

I. Askenasy, E., Über einige Beziehungen zwischen Wachstum und Temperatur. Ber. Deutsch. Bot. Gesells. 8:6I-94. I89o.

2. Bondors, G., Contribution a l'étude de influence du milieu aquatique sur les racines des arbres. Ann. Sci. Nat. Bot. IX 18: I-24. I9I3.

3. Costantin, J., Recherches sur l'influence qu'exerce le milieu sur la structure des racines. Ann. Sci. Nat. Bot. VII I: $135-178$. I885.

4. Cowles, H. C., Textbook of botany. Coulter, Barnes, Cowles. II. American Book Co. IgII.

5. Devaux, H., Recherches sur les lenticelles. Ann. Sci. Nat. Bot. VIII I2: I-240. I900.

6. Folsom, D., The influence of certain environmental conditions, especially water supply, upon form and structure in Ranunculus. Phyisol. Res. 2:209-276. I9I8.

7. Jost, L., Ein Beitrag zur Kenntniss der Athmungsorgane der Pflanzen. Bot. Zeit. 45:60I-606, 61 7-627, 633-642. I887.

8. Naвокich, A. J., Über die Wachstumsreize. Beih. Bot. Centralbl. 26:7-I49. I9IO.

9. Pedersen, R., Haben Temperaturschwankungen als solche einen ungünstigen Einfluss auf das Wachstum? Arb. Bot. Inst. Würzburg I : 563-583. I874.

ro. Pfeffer, W. (Ewart), Physiology of plants. Oxford. Igoo.

II. Schaibel, F., Physiologische Experimente über das Wachstum und die Keimung einiger Pflanzen unter verminderten Luftdruck. Fünfstücks Bei. Wiss. Bot. 4:93-I48. I900.

12. Schench, H., Über das Aërenchym, ein dem Kork homologes Gewebe bei Sumpfpflanzen. Jahrb. Wiss. Bot. 20:526-574. I889.

13. SNow, L. M., Contributions to the knowledge of the diaphragms of water plants. I. Scirpus validus. Вот. GAz. 58:495-5I7. I9I4.

I4. TRUe, R., Turgor and temperature on growth. Ann. Botany 9:365-402. I 895 .

15. WIEler, A., Die Beeinflussung des Wachsens durch verminderte Partiärpressung des Sauerstoffs. Untersuch. Bot. Inst. Tübingen I:I86-282. I883.

16. - Die Function der Pneumethoden und des Aërenchyms. Jahrb. Wiss. Bot. 32: 503-524. 1898 . 